\title{
Vegetative Response to Prescribed Fire in a North Florida Flatwoods Forest
}

\author{
WILLIAM H. MOORE, BENEE F. SWINDEL, AND W. STEPHEN TERRY
}

\begin{abstract}
Selected naturally regenerated flatwoods forests were burned in preparing a large, long-term study of the effects of several multiple use management practices on forest vegetation and wildlife. Early effects of burning on understory vegetation are reported here. Fire reduced woody understory coverage (from 72 to $66 \%$ of surface area), and increased herbaceous species frequency (from 60 to $81 \%$ ) and herbaceous standing biomass (from 124 to $245 \mathrm{~kg} / \mathrm{ha}$ ). Graphical analyses show an increase in herbaceous species diversity as a result of burning.

Successful production of wood, cattle, and wildlife in the southern pinelands depends on methods of managing both overstory and understory simultaneously to increase multiple product yields while avoiding environmental and ecological degradation. In 1976 a large study was begun to examine various effects of an array of forest management practices on wildlife, wildlife habitat, and herbage production. Portions of the study areas have only been burned. Reported here is an early assessment of the effects fire produced on the understory vegetation. Our objective is to show in a simple but compelling way certain beneficial effects of prescribed fire in a forest ecosystem.
\end{abstract}

\section{Study Area and Methods}

The 73-ha experimental area is on the University of Florida's Austin Cary Memorial Forest near Gainesville, Alachua County, Fla. When this study began the area was occupied by a 50-year old mixed stand of slash and longleaf pine averaging $20.7 \mathrm{~m}^{2}$ of basal area per ha. (This overstory was apparently not altered by the fires described in this paper.) Soils on about $70 \%$ of the experimental area are mainly a sandy, siliceous, hyperthermic Ultic haplaquod of the Pomona series. These soils are acid sands that contain an organic stain layer between 41 and $61 \mathrm{~cm}$, and a clay layer at about $109 \mathrm{~cm}$. Basinger fine sand (a siliceous, hyperthermic Spodic psammaquent), which occurs at slightly lower elevations, occupies about $15 \%$. Sparr sand (a loamy, siliceous, hyperthermic Grossarenic paleudult) and Adamsville sand (a hyperthermic, uncoated Aquic quartzipsamment) occur at slightly higher elevations and occupy most of the remaining $15 \%$ of the area.

The entire experimental area was prescribe-burned during the winter of 1975-76. Prior to that, the forest had been protected from fire and other disturbances for many years, and consequently the understory was dominated by shrubs, mainly saw-palmetto and common gallberry. Bracken fern was plentiful and pineland threeawn was common in open spaces. Other herbaceous species were scarce and hard to find.

Burning was designed to consume as much surface litter and understory biomass as possible with minimum damage to overstory vegetation. The objectives were to improve light penetrations and to expose seeds of desirable plants to mineral soil. Burning took place during February, two or three days after a rain while the

\footnotetext{
Authors are research wildlife biologist (retired) and research forester, Southeastern Forest Exp. Sta., U.S. Forest Serv. and range research biologist, School of Forest Resources and Conservation, Univ, of Florida, Gainesville 3261i.
}

soil was moist, air temperature cool, relative humidity high, and wind light and steady. The results were extensive dieback of many shrubs, but shrub consumption by flames was far from complete.

In September and October of 1976, six 1-ha plots randomly dispersed over the experimental area were selected for subsequent burning and the understory vegetation on these plots was surveyed. Three 30-m line transects were randomly located in each plot and monumented so they could be relocated.

Coverage of all woody vegetation less than $1.5 \mathrm{~m}$ aboveground was determined by measuring to the nearest centimeter the portion of each transect covered by crowns of each woody species. In those spaces where woody plants did not cover the transect, measure-

Table 1. Canopy coverage $(\%)$ below $1.5 \mathrm{~m}$ of woody plants on line transects following prescribed fires in February 1976 and in February 1978.

\begin{tabular}{lcc}
\hline \hline Species & 1976 & 1978 \\
\hline Trees & & \\
Red maple (Acer rubrum) & 0.4 & $<0.05$ \\
Sweetgum (Liquidambar styraciflua) & 0.9 & 0.6 \\
Redbay (Persea borbonia) & $<0.05$ & $<0.05$ \\
Bluejack oak (Quercus incana) & 0.9 & $0.2^{*}$ \\
Water oak (Q. nigra) & 0.2 & 0.2
\end{tabular}

Shrubs

Dwarf paw paw (Asimina parvifolia) $\quad 0.4 \quad 0.2$

Gopherapple (Chrysobalanus oblongifolius) $0.1<0.05$

Dwarf huckleberry (Gaylussacia dumosa) $\quad 3.9 \quad 6.1^{* *}$

Large gallberry (Ilex coriacea)

0.0

Common gallberry (I. glabra)

14.7

Virginia-willow (Itea virginica)

0.4

Wicky (Kalmia hirsuta)

0.7

Lyonia (Lyonia spp.)

Southern waxmyrtle (Myrica cerifera)

2.2

0.8

Running oak (Quercus pumila)

Piedmont azalea (Rhododendron canescens) 0.3

Shining sumac (Rhus copallina)

Smooth sumac ( $R$. glabra)

Poison sumac ( $R$. vernix)

Saw-palmetto (Serenoa repens)

Red chokeberry (Sorbus arbutifolia)

Queensdelight (Stillingia sylvatica)

Blueberry (Vaccinium spp.)

Ground blueberry ( $V$. myrsinites)

$<0.05$

0.1

0.1

27.5

0.6

$<0.05$

2.0

5.0

$1.3^{* *}$

$11.1^{* *}$

0.1

0.5

$1.5^{* *}$

1.0

$8.7 * *$

0.0

$<0.05$

$<0.05$

$<0.05$

$22.0^{* *}$

1.1

0.1

$2.5^{*}$

4.6

Vines

Yellow jessamine (Gelsemium sempervirens)

1.2

$$
0.9
$$

Japanese honeysuckle (Lonicera japonica)

0.0

Blackberry (Rubus spp.)

Earleaf greenbrier (Smilax auriculata)

Laurel greenbrier (S. laurifolia)

1.1

0.5

Muscadine grape (Vitis rotundifolia)

0.0

2.4

0.5

0.9

0.4

$<0.05$

1.7

*implies change is significant at $5 \%$ level.

* implies change is significant at $1 \%$ level. 
ments of surface litter coverage were recorded. To determine herbaceous composition each transect was divided into $10030-\mathrm{cm}$ segments. In each segment, any particular herbaceous species was tallied as present if any living part of a plant of that species intercepted a vertical projection of the transect segment between ground level and $1.5 \mathrm{~m}$. Otherwise, the species was recorded as absent. Percentages of segments occupied by each species on each transect measure herbaceous species frequencies (Brown 1954). Herbage standing biomass was determined by clipping two $1-\mathrm{m}^{2}$ subplots adjacent to each of the 18 transects. Clipped biomass was sorted by species, dried, and weighed to determine dry weights in $\mathrm{kg}$ / ha for each herbaceous species encountered.

Subsequent to the second survey, the six 1-ha plots were again burned by prescription, as described above, during the winter of 1977-78. In September and October of 1978 vegetation was resurveyed exactly as in 1976 except that biomass plots were moved to avoid any residual biases due to previous clipping.

The resulting observations were treated as six replications of a single treatment (1978 data) versus a control (1976 data) and subjected to paired $t$ tests (Ostle 1963) to determine which species responded significantly to burning. All changes mentioned in the text were significant at the $1 \%$ level $(P<0.01)$ unless indicated otherwise.

\section{Results}

\section{Changes in Woody Plant Coverage}

The 1977-78 burn, apparently more intense than the previous one, reduced total woody understory coverage (Table 1). Litter coverage was reduced from $17.7 \%$ to $8.7 \%$. Coverage of the most abundant shrubs (saw-palmetto and common gallberry) was reduced. Of the other important shrubs, cover of dwarf huckleberry and running oak increased and ground blueberry was unchanged.

\section{Changes in Herbaceous Species Frequencies}

With the reductions in woody cover and surface litter, herbaceous vegetation frequencies increased (Table 2). Frequencies within the most important forage class, namely grasses, generally increased. Pineland threeawn frequency increased from 11.0 to $17.8 \%$. Grasses of greater importance to wildlife and cattle (Andropogon, Panicum, Paspalum) did not significantly increase. Ferns (predominantly bracken fern - the single most abundant herbaceous species) apparently increased $(P<0.05)$ after burning. Forbs were common and exhibited varied response to burning. For example, grassleaf goldaster remained unchanged while the asters were diminished. On the other hand, legumes (among the most important wildlife foods) and Eupatorium increased. Grasslikes (see Table 2) were few and their response seems relatively unimportant.

\section{Changes in Herbage Biomass}

Biomass sampling revealed few significant weight changes due to burning (Table 2). Most significant was the response of pineland threeawn which increased from 9 to $32 \mathrm{~kg} / \mathrm{ha}$. Few other differences were established beyond doubt (although the second burn may have doubled herbage production) indicating that biomass sampling intensity was inadequate.

\section{Discussion}

It is important to consider the total floral response to various forest and range management practices. Forest management (especially in the slash pine ecosystem) has been subjected to the criticism that it too often tends to produce a pine monoculture which excludes other plant species on lands planted to pines. Burning, as a specific practice, is not often so criticized. Indeed, fire is widely recognized as a tool for preserving floral diversity, for it discriminates against overabundant woody species that may dominate sites when fire is excluded. Thus, prescribed burning can encourage the reinvasion of various herbaceous species (many of them beneficial

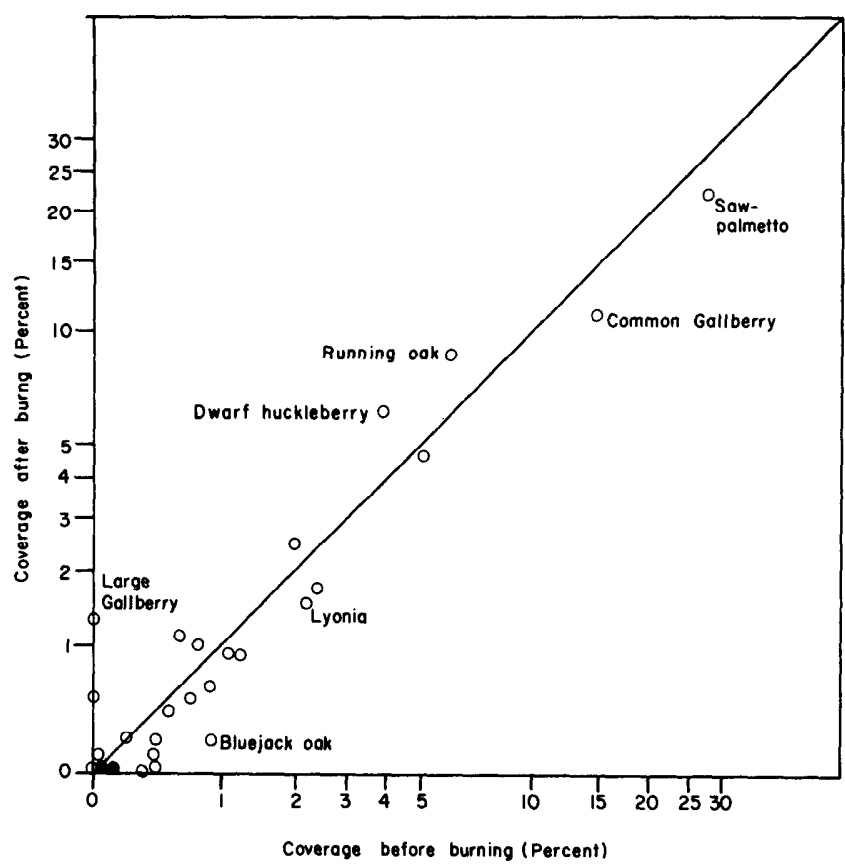

Fig. 1. Coverage of woody species below 1.5 meters before and after second prescribed fire. (Plotted straight line delineates no change. Open circles indicate responses of single species; shaded circles, more than one species. Named species responded significantly $(P<0.01)$ to burning.)

to wildlife and cattle) if seed sources are available (White 1975). It is instructive to examine the response to prescribed fire detailed in previous sections with these considerations in mind.

Coverage of woody species in the understory before and after the 1977-78 winter burn are depicted in Figure. 1. Coverage before burning is plotted (on a logarithmic scale) along the abscissa, coverage after burning in a similar way along the ordinate of the graph. Thus, it appears from the graph that common gallberry covered about $15 \%$ of the transects before burning, and $11 \%$

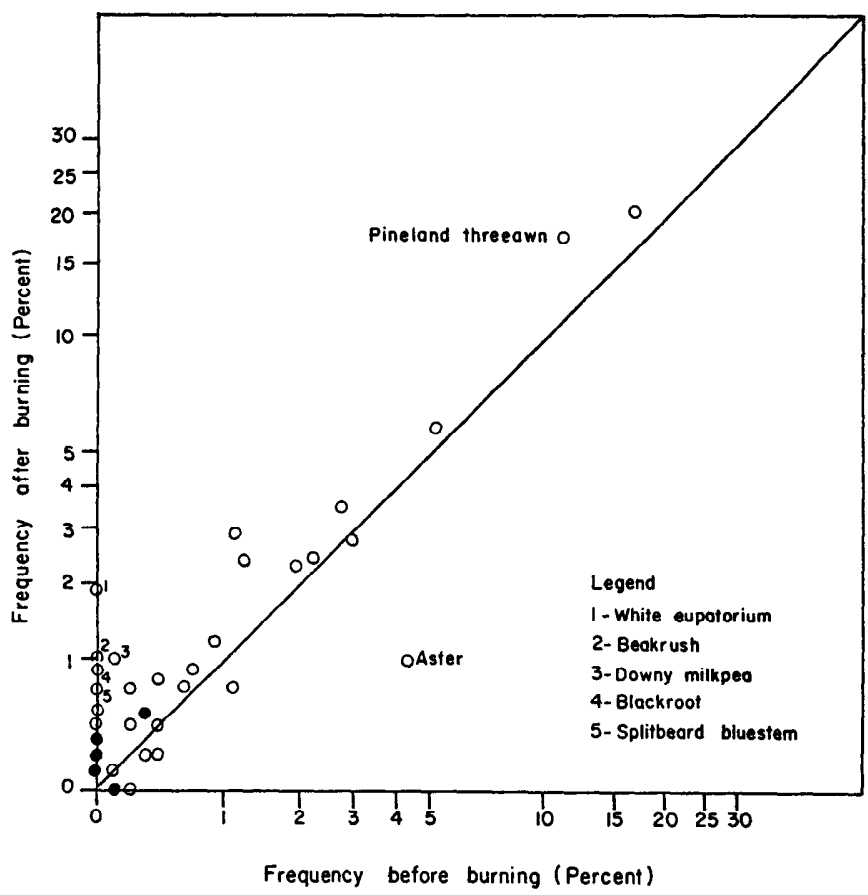

Fig. 2. Frequency of herbaceous vegetation before and after second prescribed fire. (Plotted straight line deliniates no change. Open circles indicate responses of single species; shaded circles, more than one species. Named species responded significantly $(\mathbf{P}<0.01)$ to burning.) 
Table 2. Frequency of occurrence of herbaceous plants on line transects following prescribed fires in February 1976 and February 1978, and corresponding standing biomass on clipped subplots.

Frequency (\%)

Biomass (kg/ha)

Species

1976

1978

Perennial goobergrass (Amphicarpum muhlenbergianum)

Chalky bluestem (Andropogon capillipes)

0.0

1.2

Creeping bluestem (A. stolonifer)

Fineleaf bluestem (A. subtenuis)

Splitbeard bluestem ( $A$. ternarius)

Broomsedge bluestem (A. virginicus)

Green silkyscale (Anthaenantia villosa)

Arrowfeather threeawn (Aristida purpurascens)

Bottlebrush threeawn (A. spiciformis)

Pineland threeawn (A. stricta)

Toothachegrass (Ctenium aromaticum)

Shaggy fingergrass (Digitaria villosa)

Lovegrass (Eragrostis spp.)

Panicum (Panicum spp.)

Beaked panicum ( $P$. anceps)

Creeping panicum ( $P$. dichotomum)

Maidencane ( $P$. hemitomon)

Warty panicum ( $P$. verrucosum)

Barestem paspalum (Paspalum longepedunculatum)

Knotroot bristlegrass (Setaria geniculata)

Lopside indiangrass (Sorghastrum secundum)

Curtiss dropseed (Sporobolus curtissii)

Grasslikes

Flatsedge (Cyperus spp.)

Maidenhair spikesedge (Eleocharis vivipara)

Common rush (Juncus effusus)

Beakrush (Rhynchospora spp.)

Razorsedge (Scleria spp.)

Ferns

Cinnamon fern (Osmunda cinnamomea)

Bracken fern (Pteridium aquilinum)

16.7

Forbs

Stargrass (Aletris spp.)

Aster (Aster spp.)

Yellow balduina (Balduina uniflora)

†Showy partridgepea (Cassia fasciculata)

†Coastal butterflypea (Centrosema virginianum)

+Showy crotalaria (Crotalaria spectabilis)

$\dagger$ Beggarweed (Desmodium spp.)

Virginia buttonweed (Diodia virginiana)

Elephantfoot (Elephantopus tomentosus)

Eryngo (Eryngium aromaticum)

Button snakeroot (E. yuccifolium)

Eupatorium (Eupatorium spp.)

White eupatorium (E. album)

Dogfennel eupatorium ( $E$. capillifolium)

Spurge (Euphorbia spp.)

†Downy milkpea (Galactia volubilis)

Grassleaf goldaster (Heterotheca graminifolia)

St. Johnswort (Hypericum spp.)

Pinweed (Lechea spp.)

Gayfeather (Liatris garberi)

Blackroot (Pterocaulon pycnostachyum)

Meadowbeauty (Rhexia spp.)

†Catclaw sensitivebriar (Schrankia microphylla)

Goldenrod (Soldiago spp.)

Shoe-buttons (Sygonanthus flavidulus)

†Brownhair tephrosia (Tephrosia spicata)

Stinging nettle (Urtica chamaedryoides)

Wood violet (Viola triloba)

Yelloweyedgrass (Xyris ambigua)
0.1

2.4

2.4

0.1

$0.7^{* *}$

2.8

0.0

0.1

0.2

$17.8^{* *}$

0.5

0.1

0.1

3.5

0.5

0.1

0.1

0.1

0.7

0.2

0.2

0.8

0.4

$1.2^{*}$

0.1

$1.0^{* *}$

2.3

0.9

$20.6^{*}$

0.1

$1.0^{* *}$

0.1

2.9*

0.0

0.1

0.0

$0.3^{*}$

0.3 *

0.4

0.2

0.5

$1.9^{* *}$

0.1

0.7

$1.0^{* *}$

5.8

1.2

0.1

0.1

$0.9^{* *}$

0.7

0.1

0.1

0.2

0.4

0.1

0.2

0.0

1976

1978

1976

1

$<0.5$

8

0

0

7

0
$<0.5$

$<0.5$

32**

$<0.5$

0

0

4

18

0

0

0

$<0.5$

$<0.5$

4

0

$<0.5$

1

3

1

8

105

$0^{* *}$

0

19

0

1

0

0

0

0

0

4

0

1

12

12

0

0

6*

2

0

0

0

$<0.5$

1

0
0

$\nmid$ Legumes (all FABACEAE)

$4.5^{*}$

*Implies change is significant at $5 \%$ level.

**Implies change is significant at $1 \%$ level. 
afterwards ( $c f$. Table 1). The straight line at $45^{\circ}$ is not a fitted regression line, but simply the line of exactly no change. Species that diminish after burning plot below the line, those that increase plot above it. Only those species that changed significantly $(P<0.01)$ are named. Examining the entire graph for the collective response of the community, the apparent affect of fire is slight, but discernable, reduction in the coverage of woody understory plants. It is interesting from an ecological viewpoint that the reduction is relatively no more severe in relatively rare species than in relatively common ones. Indeed, examination of the two axes of the graph show that three species (including large gallberry) appea red on the transects only after burning compared to one species that appeared only before burning. Thus, there were 32 species of woody plants observed in the understory covering the transects after burning compared to 30 species observed before ( $c f$. Table 1).

Frequency responses of the herbaceous understory are plotted in an analogous way in Figure 2. Thus, it appears from that graph that frequency of pineland threeawn increased from about $11 \%$ prior to burning to about $18 \%$ afterwards ( $c f$. Table 2). From this graph the response of the herbaceous understory is just opposite that of the woody understory and somewhat more pronounced. The clearly dominant tendency is that herbaceous plants increase in numbers whether they be relatively rare or common prior to burning. And substantial numbers of herbaceous species appear only after burning. Thus, 18 species of grasses were observed on the transects before burning, 25 afterwards. Fourteen species of forbs were observed before burning, 29 species afterwards. In all, 37 herbaceous species were identified on the transects before burning, 61 species afterwards. Only aster among herbaceous species was significantly reduced.

Finally, herbaceous biomass is plotted in an analogous way in Figure 3. Recall that the destructive sampling employed required that biomass harvesting be performed on distinct subplots during resurvey. The resulting greater variation in the two observations is expressed in greater scatter and in the fact that only pineland threeawn and aster are deemed to be significantly changed. Still, the dominant trend of herbaceous species, whether rare or common before burning, is to increase in weight after burning.

\section{Conclusions}

Evidence in this study indicates that prescribed fire in flatwoods forests of north Florida diminishes overabundant woody understory cover. The diminution is relatively uniform over the spectrum from rare to common species. There is no evidence in our data that burning actually reduces the total number of woody species in the understory.

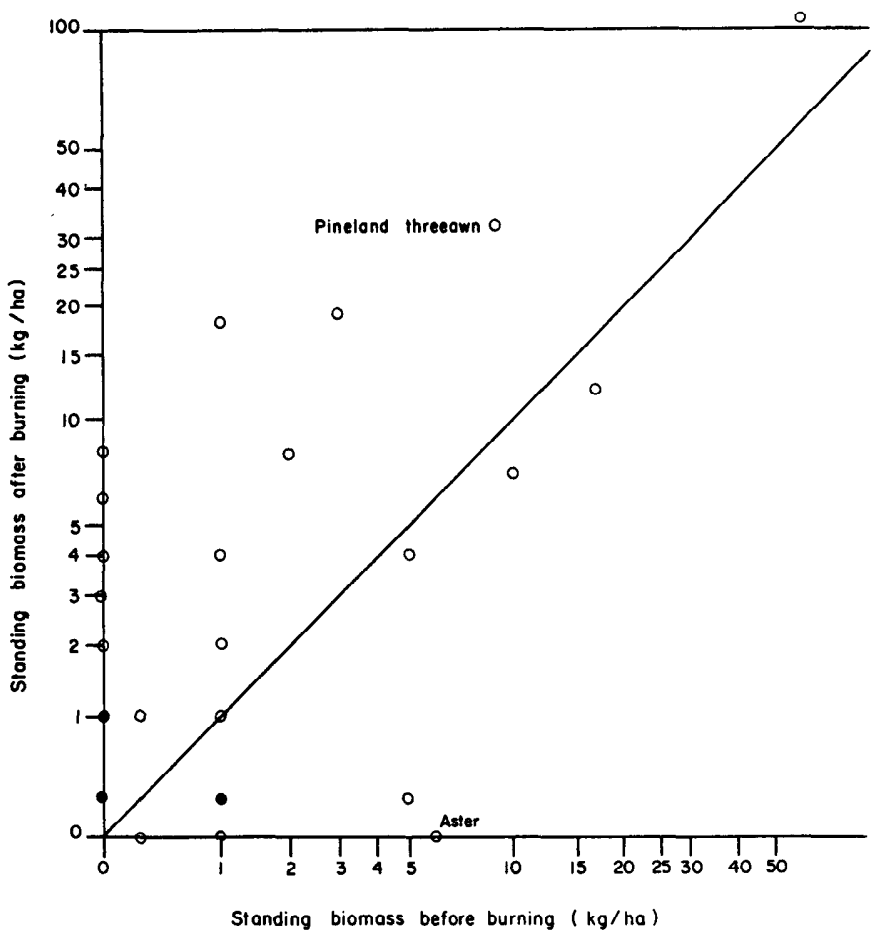

Fig. 3. Herbaceous standing biomass before and after second prescribed fire. (Plotted straight line deliniates no change. Open circles indicate responses of single species; shaded circles, more than one species. Named species responded significantly ( $\mathrm{P}<0.01$ to burning.)

The response of the herbaceous understory is just the converse and more pronounced. Burning tends to increase both frequency and weights of herbaceous species, including those that were previously rare. Thus, total number of understory species and understory species diversity are apparently increased by prescribed fire.

\section{Literature Cited}

Brown, D. 1954. Methods of surveying and measuring vegetation. Bull. 42. Commonwealth Bureau of Pastures and Field Crops. Hurley, Berks, England. 223 p.

Ostle, B. 1963. Statistics in research. The Iowa State University Press, Ames. $585 \mathrm{p}$.

White, L.D. 1975. Intensive forest management effects on understory plant production. p. 76-89. In: Forest Soils of the Southeastern Coastal Plains. Sch. Forest Res. and Conserv. Res. Rep. No. 2. Univ. Florida, Gainesville. 